\title{
The relationship between intercultural sensitivity and English language achievement
}

\author{
Fatma Çiloğlan $^{\mathrm{a} *}$ (iD), Mehmet Bardakçı b \\ ${ }^{a}$ Hasan Kalyoncu University, Gaziantep, 27900, Turkey \\ ${ }^{b}$ Gaziantep University, Gaziantep, 27010, Turkey
}

\section{APA Citation:}

Çiloğlan, F., \& Bardakçı, M. (2019). The Relationship between Intercultural Sensitivity and English Language Achievement. Journal of Language and Linguistic Studies, 15(3), 1204-1214.

Submission Date:07/02/2019

Acceptance Date:23/07/2019

\begin{abstract}
The present descriptive study aims to investigate whether there is a relationship between intercultural sensitivity and language achievement of learners of EFL in Turkey. To this aim, a descriptive research design based on the quantitative research methodology was used. The number of female participants was 120, and that of the male participants was 205. A total of 325 participants who were attending preparatory school at a state university were selected using random cluster sampling. The "Intercultural Sensitivity Scale" developed by Chen and Starosta was used to obtain the quantitative data. The findings showed that there is a weak statistically significant positive correlation between intercultural sensitivity and English language achievement of learners of English as a foreign language in Turkey. However, there was a significant difference between the intercultural sensitivity scores of the participants regarding the English language proficiency levels. The results displayed that the higher the proficiency level, the greater the intercultural sensitivity scores are. Additionally, findings indicated that there was not a significant difference between intercultural sensitivity scores of the female and male participants
\end{abstract}

(C) 2019 JLLS and the Authors - Published by JLLS.

Keywords: Intercultural sensitivity; English language proficiency; language achievement; intercultural competence; Turkish context

\section{Introduction}

With the increased interest in intercultural sensitivity in the globalizing and multicultural society all through in recent years, disorientation related to this concept has raised, too. Intercultural sensitivity, as an element of intercultural competence, has not entirely been comprehended yet. According to Chen and Starosta (1996, p. 2), the major problem of the disorientation is to misperceive these three concepts; "intercultural sensitivity, intercultural awareness and intercultural communication competence". The three are separate concepts, even though they are closely related. Intercultural communication competence is a generic term that is composed of interactants' ability to be effective, behaviorally and cognitively in the development of intercultural communication. Namely, intercultural awareness is expressed through the cognitive elements of intercultural communication competence, which means "the understanding of cultural conventions that affect how we think and behave" (Chen, 2010, p. 35). The

\footnotetext{
* Corresponding author. Tel.: +0-000-000-0000

E-mail address: ciloglan_fatma@hotmail.com
} 
intercultural sensitivity concept which means the subjects' "active desire to motivate themselves to understand, appreciate, and accept differences among cultures" (Chen \& Starosta, 1996, p. 367) stands for the intercultural communication competence's affective aspects. Bennett (2017) defined intercultural sensitivity as the ability of interactants to renovate themselves cognitively, effectively and behaviorally from refusal phase of the aspect of cultural differences to inclusion phase of this cultural variation in the intercultural communication developmental process. It indicates that people who have intercultural sensitivity are capable of proceeding to the dual identity level and appreciate cultural diversity by progressively outfacing the problems of concealing or denying the existence of cultural diversities. These individuals can maintain their perspectives and enhance empathic ability to embrace and orient themselves to different cultures. The confusion in these concepts lays an obstacle for intercultural training programs as well.

Intercultural training programs are directly affected by these confusions in these concepts; hence, it also impacts foreign language learning. Cognitive training, affective training, self-awareness training, behavioral training and cultural awareness training which are some of the intercultural training programs, intended to aid participants to build an understanding and appreciation of interactional skills and cultural stimuli (Cushner \& Brislin, 1996). Therefore, it is also relevant to language learning because every language inherits the cultural characteristics of its own and one who aims to learn another language is required to accept the cultural characteristics of that language as well.

For this reason, many research dealt with intercultural communication competence in language learning (Alptekin 2002; Bayyurt 2013; Byram, Gribkova \& Starkey 2002; Lo Bianco, Liddicoat \& Crozet 1999; Sarıçoban \& Öz 2014); as a result, intercultural sensitivity was left behind, and its importance in language learning was ignored. Although intercultural sensitivity can be assumed to be an aspect that is closely related to language and language learning, there have been few studies investigating the relationship between intercultural sensitivity and language learning (Engle \&Engle 2004, Jackson 2011).

In creating the research questions and the present study's data collection, the sociocultural theory of Vygotsky (1979) and Deardorff's (2006) research concerning intercultural sensitivity and its connection with language learning and achievement played a large role. In planning the investigation, the research literature and models were examined in order to find what they provide or do not provide to us on the relationship between intercultural sensitivity and English language achievement.

The sociocultural theory considers EFL occurrence as a social product. According to the theory, the interaction between people from different cultural and linguistic backgrounds is the foundation of EFL development. This development process emerges due to the exchange of identities and cultures through interaction between the interlocutors. As a result of this exchange of the differences a "communities of practice" is formed which could be identified by the three themes stated below (Wenger 1999), (1) mutual involvement in common practices, (2) involvement in some mutually negotiated enterprise, and (3) benefiting from the common repertoire of the members.

Accordingly, intercultural sensitivity is commonly conceptualized as "the ability to discriminate and experience relevant cultural differences" (Hammer, Bennett \& Wiseman 2003, p. 422)". The more interculturally sensitive an individual is, the more interculturally competent she/he can be as the researchers in this field have noted "greater intercultural sensitivity is associated with greater potential for exercising intercultural competence" (Hammer et al. 2003, p. 422) similar to some others (Penbek, Yurdakul \& Cerit 2012). A variety of frameworks and models have been developed within the cultural studies' field, (Hart, Carlson \& Eadie 1980) with the aim of presenting a profounder insight of intercultural sensitivity by handling the concept as a mindset, a progressive stage (Gudykunst \& Hammer, 1983) or a general ability for intercultural communication (Bennett \& Paige 1993, Bhawuk \& 
Brislin 1992). In spite of their different points of view, these models and frameworks offered a base for the conceptualization of intercultural sensitivity. Chen and Starosta (1997) indicated that intercultural sensitivity is fundamentally related to emotions, even though it is also concerned with the effective, behavioral and cognitive parts of interactions.

In the present study, the relationship between intercultural sensitivity, which has not been studied in the context of language learning or acquisition, and English language achievement of EFL learners in Turkey will be investigated. Although there have been some studies related to Intercultural Sensitivity (Alptekin 2002; Bayyurt 2013; Byram, et al. 2002; Engle \& Engle 2004; Jackson 2011; Lo Bianco et al. 1999; Sarıçoban \& Öz 2014; Vila Banos 2006), there have not been any studies similar to the drive of this research in the context of Turkey. Therefore, this study objects to bridge the gap in this field in the Turkish context and to provide a new aspect that might be beneficial in language learning and teaching which can lead to new studies broadening the path between intercultural sensitivity and foreign language achievement. For this purpose, responses to the following research questions were sought.

1. Is there a relationship between intercultural sensitivity and English language achievement of EFL learners in Turkey?

2. Is there a statistically significant difference in the scores of intercultural sensitivity scale regarding the proficiency levels of the EFL learners?

3. Is there a statistically significant difference in the scores of intercultural sensitivity scale regarding genders of the EFL learners?

\section{Method}

\subsection{Participants}

The participants were 325 (120 females and 205 males) EFL students attending an intensive English program in the School of Foreign Languages of a state university. The participants were elementary (A2: 32) and intermediate (B1: 228, B2: 65) levels whose age ranged between 18 and 26. The random cluster sampling method, which is a sampling strategy in which the size and the distribution of the clusters are unknown before sampling and display a characteristic which is of interest to the sample survey, was used during the selection procedure (Pfeffermann \& Rao, 2009, p.118). Permission from the School of Foreign Languages was granted for the purpose of this study and the administration of the Intercultural Sensitivity Scale (ISS).

\subsection{Instrument(s)}

The survey used in the present study consisted of two parts. The first part involved a demographic information section and the second part involved the Intercultural Sensitivity Scale (ISS). The scale consisted of 24 statements about the individual's intercultural sensitivity to be answered to in a fivepoint Likert-type scale, developed by Chen and Starosta (2000).

Prior to the ISS administration, it was translated into Turkish by two professional translators specialized in English language teaching and back-translated by two other translators to ensure accuracy. Following the translation, the ISS was piloted to 71 ELT students to ensure the reliability and validity of the Turkish version of ISS. Half of the students required to fill the Turkish version, while the other half was asked to fill the English version of the scale. After ten days the same procedure was followed the other way around. According to the analysis, the Alpha Coefficient for twenty-four items in the ISS 
scores of participants were found to be .83 , signifying that the items have relatively high internal consistency. The correlation between English items and Turkish translated items was found to be .71 . The result indicates that the Turkish version of ISS is valid and reliable and suitable to be used in the Turkish context.

\subsection{Research design and data collection procedures}

The present study employed a descriptive research design based on a quantitative approach. It is "designed primarily to describe what is going on or what exists" (Trochim \& Donnelly, 2001, p. 5). The present study investigates a major issue in an effort to answer the three research questions mentioned above and was conducted using a correlational survey model.

The first phase of data collection was composed of the administration of the Intercultural Sensitivity Scale (ISS) to 325 students, who consented to participate in the study, from different foreign language levels in the preparatory program at a state university. In the second phase of the data collection process, the participants' final exam scores were collected.

\subsection{Data analysis}

After completing the data collection process, the SPSS program was used for the analysis of the data. The responses of the 325 participants to the demographic part of the ISS were coded accordingly. Although there were 22 unmatched final exam scores, the final exam scores of 303 participants were obtained and Pearson's product moment correlation analysis was applied. Before performing any analysis, the normal distribution of the ISS scores was checked by Skewness and Kurtosis on SPSS (Skewness 1,296, Kurtosis 0,392) the scores of participants in three proficiency levels and the scores of genders were ensured to find out if the variances were equal (Büyüköztürk, 2006). The Pearson's product moment correlation analysis was applied to analyze the correlation between intercultural sensitivity and EFL learners' English language achievement in Turkey. The one-way analysis of variance (ANOVA) was applied to find the difference in the scores of ISS regarding the proficiency levels, and an Independent Samples t-test was performed to assess the difference in the scores of ISS regarding gender.

\section{Results}

The first research question investigates the relationship between participants' ISS scores and their English language achievement obtained from the final exam administered at the end of the 2017-2018 academic year. Pearson product moment correlation was used to determine the relationships between the ISS scores and English language achievement When the Pearson Moments Multiplication Correlation Coefficient is evaluated, if the coefficient is lower than 0.30 , it indicates that the correlation is weak and if it is lower than 0.05 , it indicates that the findings are statistically significant (Büyüköztürk, 2006).

As a result of the analysis, a positive correlation was found between ISS scores and English language achievement. The correlation coefficient was noted .014 and p-value was .810 which indicates that there is a weak positive correlation and it is not statistically significant (Büyüköztürk, 2006).

For the second research question, the one-way analysis of variance (ANOVA) was used to compare the means of ISS scores of the students from A2, B1, B2 language proficiency levels to find out whether any of these means is significantly different from each other. The independent variable was proficiency 
levels, A2, B1, B2, and the dependent variable was ISS scores. The means of the groups and standard deviations are given in Table 1 .

Table 1. Descriptive Statistics of Preparatory School Students' Intercultural Sensitivity Scale Scores

\begin{tabular}{llll}
\hline Language Proficiency Levels & $n$ & $M$ & $S D$ \\
\hline A2 & 32 & 90,50 & 15,48 \\
B1 & 228 & 85,63 & 13,55 \\
B2 & 65 & 96,80 & 11,79 \\
Total & 325 & 88,34 & 14,11 \\
\hline
\end{tabular}

Table 1 indicates that the intercultural sensitivity scores of Turkish preparatory school students were high with a mean ISS score which is 88.34. It refers to that the total of A2, B1 and B2 level participants, which stands for Turkish learners, presents a high intercultural sensitivity. While the minimum ISS score was 39, the maximum score was 120 .

The test for homogeneity of variance was not significant [Levene's $F(2.524)=.0 .82, \mathrm{p}>.05$ ] indicating that the variance within each of the populations was equal.

Table 2. Analysis of Variance for Preparatory School Students' ISS Scores and Language Proficiency Levels

\begin{tabular}{cccccc}
\hline Source & $\begin{array}{c}\text { Sum of } \\
\text { Squares }\end{array}$ & df & $\begin{array}{c}\text { Mean } \\
\text { Square }\end{array}$ & F & p \\
\hline $\begin{array}{c}\text { Between } \\
\text { Groups }\end{array}$ & 6468.52 & 2 & 3234.26 & 17.936 & .000 \\
$\begin{array}{c}\text { Within } \\
\text { Groups }\end{array}$ & 58063.18 & 322 & 180.32 & & \\
Total & 64531.71 & 324 & & & \\
& & & &
\end{tabular}

The significance level for the one-way analysis of variance (ANOVA) is $.000(p=0.05)$. According to the one-way ANOVA of ISS $(\mathrm{F}, 17.936=.000, \mathrm{p}<.001)$, there was a statistically significant difference in the means of three proficiency levels as shown in Table 2 above. As the analysis stated, there was a significant difference in the means of three groups of ISS, post-hoc LSD tests were conducted to find out the specific significant differences between groups. 
Table 3. Post-hoc LSD tests for Preparatory School Students' ISS Scores and Language Proficiency Levels

\begin{tabular}{ccccc}
$\begin{array}{c}\text { Depended } \\
\text { Variable }\end{array}$ & $\begin{array}{c}\text { (I) } \\
\text { Proficiency } \\
\text { Level }\end{array}$ & $\begin{array}{c}\text { (J) } \\
\text { Proficiency } \\
\text { Level }\end{array}$ & $\begin{array}{c}\text { Mean } \\
\text { Deviation }\end{array}$ & $\mathrm{p}$ \\
\hline ISS Scores & $\mathrm{A} 2$ & $\mathrm{~B} 1$ & 4.86 & .056 \\
& & $\mathrm{~B} 2$ & -6.30 & .031 \\
& $\mathrm{~B} 1$ & $\mathrm{~A} 2$ & -4.86 & .056 \\
& & $\mathrm{~B} 2$ & -11.16 & .000 \\
& $\mathrm{~B} 2$ & $\mathrm{~A} 2$ & 6.30 & .031 \\
& & $\mathrm{~B} 1$ & 11.16 & .000 \\
\hline
\end{tabular}

According to Table 3, the post-hoc LSD test results indicates that the mean difference (-6.30) between the ISS scores of A2 and B2 language proficiency levels had a statistically significant difference $(\mathrm{p}<.05)$. Similarly, the mean ISS scores of B1 and B2 language proficiency levels $(-11.16)$ had a statistically significant difference ( $\mathrm{p}<.01)$. However, there was not any statistically significant difference between the mean differences of ISS scores of A2 and B1 language proficiency levels ( $p>.05)$.

To compare the mean of ISS of the participants regarding gender, an independent-samples t-test was performed.

Table 4. Independent t-test results of Preparatory School students based on gender

\begin{tabular}{lllllll}
\hline & $\mathrm{N}$ & $\mathrm{M}$ & $\mathrm{SD}$ & $\mathrm{df}$ & $\mathrm{t}$ & $\mathrm{p}$ \\
\hline Female & 120 & 88.95 & 14.63 & 323 & .596 & .551 \\
Male & 205 & 87.99 & 13.82 & & & \\
\hline
\end{tabular}

The mean of the female participants was 88.95 , and the standard deviation was 14.63 . The mean of the male participants was 87.99 , and the standard deviation was 13.82 and p-value was .551 . The mean of female students was higher than the mean of male students. These results advocate that there was not a statistically significant difference in the means of female and male participants as Table 4 displayed.

\section{Discussion}

The result of the analyses indicated that there is no significant correlation between ISS scores and foreign language achievement. However, the participants of the study have a relatively high intercultural sensitivity score as presented in Table 1 . The number of the participants decreased to 303 in the Pearson product-moment correlation analysis due to excluding 22 participants because of the outliers

Using Chen's (1997) conceptualization of intercultural sensitivity, it can be finalized that the greater part of the participants has a high "positive emotion towards understanding and appreciating cultural differences" and consequently, they also support proper and efficient actions in intercultural communication. Although there are no corresponding studies investigating the relationship between intercultural sensitivity and English language achievement levels of EFL learners, the findings were compared with the study of Kural and Bayyurt (2016) in terms of the implementation of English as a Lingua Franca (ELF) aware intercultural competence (IC) development model. In their study, 
intercultural sensitivity was found to be contributing to the readiness and preparedness of the Turkish international graduate students prior to their departure to study in English L1 countries. It can be said that even if there is no significant correlation between ISS scores and English language achievement, learners would be positively influenced in order to have positive attitudes towards EFL.

Additionally, the finding can also be interpreted as a result of the fact that students are having more experiences with people from different cultural backgrounds in today's the social order, as traveling is much easier and safer now. It is possible to interact or encounters culturally diverse people, and under some circumstances, it is not possible to avoid getting in contact with them (Williams, 2005). Furthermore, there are programs for learners to volunteer abroad, go on adventures abroad, study abroad; and this may also allow students to have more opportunities to interact with different and new cultures, thus providing them with opportunities to develop their intercultural sensitivity as Anderson, Lawton, Rexeisen and Hubbard (2006) emphasized in their research "study abroad experience significantly improved the participants' level of intercultural sensitivity" (p. 464).

When the question of "to what extent the factors such as proficiency levels affect the intercultural sensitivity of the participants" was investigated, it was found that there is a statistically significant difference between the proficiency levels. After the post-hoc test, it was determined that there is a significant difference in the means of proficiency levels between A2- B2 levels and B1-B2. This difference might be interpreted as the more proficient the students are, the higher their intercultural sensitivity is. Except for A2 and B1 proficiency levels since participants from A2 proficiency level have a higher score than the B2 level. It could be due to their characteristics or may have resulted from being more in touch with people from diverse cultures.

The level of language proficiency has an important role when it comes to interrelating with people from diverse cultural backgrounds. As sociocultural theory emphasizes that the language is developed socially because of being a social product, development occurs through interactions. Therefore, the interaction between different cultures is required to have more intercultural sensitivity. The theory also perceives development and learning as a continuous united process of social interactions and; participation and expert guidance have vital roles in this process. Willingness and ability to communicate are required to be able to continue and participate in intercultural communication. Additionally, personality of speakers also determines their approach to a language and "They feel motivated by the interpersonal situation, likely a combination of affiliation and control motives" (MacIntyre, Dörnyei, Clément \& Noels 1998, p. 548). Thus, willingness aids the learner to continue the learning process and improve their language proficiency. Therefore, we could say that the participants at B2 language proficiency level are more proficient and encouraged to communicate in the target language as an outcome of their level of proficiency.

According to Vygotsky (1979, p. 30), "the individual dimension of consciousness is derivative and secondary". This view shows that the mental operation of individuals does not occur merely from social interaction; it requires the particular processes and structures formed by the individuals to be tracked to their exchanges with other individuals. Even though cultural exchanges are necessary, cultural differences can discourage people from being involved in cultural communication. Sometimes speakers who have different cultural backgrounds have difficulty in acknowledging cultural differences, and they prefer ignoring them and behave in line with their cultural beliefs and norms. It may result in some misunderstandings. It is necessary to establish empathy and intercultural sensitivity toward people from different cultures to be able to overcome these unpleasant results. However, in the present study, all three proficiency levels demonstrated sensitivity towards differences and they showed their enjoyment in encountering these differences. The ISS mean scores of B2 and B1 levels is supported by Wertsch's (1994) argument of nature of interdependence between the social progression and language development of individuals, which indicates a connection between social progression and language development. A2 
level, on the other hand, showed a different result as in Table 1 and indicated a higher ISS score than B1 level. The reason behind this result could be due to the multicultural environment in the classrooms due to the increased number of immigrant students at universities, especially in the south-east region.

In the present study, no significant difference was found between female and male participants in the scores of ISS. The result of the analysis showed that the difference between genders is not significant ( $p>.05)$. According to the finding, female participants and male participants have almost equal ISS scores. The findings are not in line with Vila Banos (2006), who found that female students are interculturally more sensitive than male students. This indicates that the female and male participants in this study have a nearly equal level of empathy, cultural awareness, thus, intercultural sensitivity. The findings are not similar to the statement of Cherniss, Goleman, Emmerling, Cowan and Adler (1998), who investigated men and women and their empathic abilities in his study. Cherniss et al. (1998) in their study demonstrated that "women do tend to experience this spontaneous matching of feeling with others more than men do" (Cherniss et al. 1998, p. 322).

\section{Conclusions}

This study intended to examine the relationship between intercultural sensitivity, which is one of the affective aspects of intercultural communication competence (Chen \& Starosta, 1998), and English language achievement of EFL learners in Turkey.

The first research question discovered the relationship between intercultural sensitivity and English language achievement of EFL learners in Turkey. The second research question examined the difference between the ISS scores regarding proficiency levels. The last question investigated the difference in the Intercultural Sensitivity Scale scores regarding the gender. The motive for these questions came from the proposal by Deardorff (2006), intercultural sensitivity and related literature that foreign language proficiency and intercultural sensitivity dwell on. With the aim of establishing certainty concerning these questions, it was essential to examine the aspects of intercultural sensitivity by addressing the perspectives of the colleagues who have studied in this field and the achievement in a foreign language.

As a result of the analysis, a weak correlation between ISS scores and English language achievement was found. Although there was a weak correlation between intercultural sensitivity scores and English language achievement of the participants, there was a significant difference between proficiency levels (A2, B1, and B2) in favor of the participants from higher proficiency levels. It suggests that intercultural sensitivity has a significant place in foreign language teaching and learning. It is not certain that whether being interculturally sensitive has a great impact on language development, achievement and proficiency; or being proficient in a foreign language does not state that you have a high intercultural sensitivity level. However, it is important to be empathic and tolerable towards different cultures to be able to embrace and accept both their cultural and linguistic differences. Therefore, the necessity of developing intercultural sensitivity should be realized by institutions of higher education and universities in order to enhance. As Patterson and Mughan (1999, p. 59), mentioned "Current foreign language course design in higher education is questioned for its lack of focus on understanding people of other cultures. It is therefore argued that foreign language degree courses rapidly need to adopt an approach to intercultural learning which prepares students to move with more ease amongst numerous cultures and which is less bound cognitively."

In the present study, there was not a significant difference between the ISS scores of the participants and their gender. The ISS scores of female and male participants were found to be close, although male participants were outnumbered the females. This result was not in line with previous research (Vila Banos, 2006). 
The present study indicates that although the correlation between ISS scores and English language achievement is not significant, ISS influences the learners' perception of cultural differences. Therefore, it is important for language teachers and designers to integrate activities or teaching methods by considering intercultural sensitivity to affect the proficiency level of English language learners indirectly. In consideration of the findings of this study, some techniques or programs can be developed to enhance the intercultural sensitivity level of the learners and to facilitate the language learning process.

\section{References}

Alptekin, C. (2002). Towards intercultural communicative competence in ELT. ELT journal, 56(1), 57-64.

Anderson, P. H., Lawton, L., Rexeisen, R. J., \& Hubbard, A. C. (2006). Short-term study abroad and intercultural sensitivity: A pilot study. International Journal of Intercultural Relations, 30(4), 457469.

Bayyurt, Y. (2013). Current perspectives on sociolinguistics and English language education. The Journal of Language Learning and Teaching, 3(1), 69-78.

BBennett, M. J. (2017). Developmental model of intercultural sensitivity. The International Encyclopedia of Intercultural Communication, 1-10.

Bennett, M. J., \& Paige, R. M. (1993). Education for the intercultural experience. Towards ethnorelativism: a developmental model of intercultural sensitivity, 21-71.

Bennett, M.J. (1993) "Towards Ethnorelativism: A Developmental Model of Intercultural Sensitivity." In Yarmouth, ME: Education for the intercultural experience, edited by R.M. Paige, 21-71. Intercultural Press.

Bhawuk, D. P., \& Brislin, R. (1992). The measurement of intercultural sensitivity using the concepts of individualism and collectivism. International journal of intercultural relations, 16(4), 413-436.

Büyüköztürk, Ş. (2006). Sosyal Bilimler İçin Veri Analizi El Kitabı. Ankara: Pegem A Yayıncılık.

Byram, M., Gribkova, B., and Starkey, H. (2002). Developing the intercultural dimension in language teaching. A practical introduction for teachers. Strasbourg: Council of Europe.

Chen, G. M. \& Starosta, W. J. (1997). A review of the concept of intercultural sensitivity. Human Communication, 1, 1-16.

Chen, G. M. (2010). A Study of Intercultural Communication Competence. Hong Kong: China Review Academic Publishers. https://doi.org/10.4018/978-1-61520-773-2.ch051.

Chen, G. M., \& Starosta, W. J. (1996). Intercultural communication competence: A synthesis. Annals of the International Communication Association, 19(1), 353-383.

Chen, G. M., \& Starosta, W. J. (1998). A review of the concept of intercultural awareness. Human Communication, 2(1), 27-54.

Chen, G. M., \& Starosta, W. J. (2000). The development and validation of the intercultural sensitivity scale. Human Communication, 3, 3-14. 
Cherniss, C., Goleman, D., Emmerling, R., Cowan, K., \& Adler, M. (1998). Bringing emotional intelligence to the workplace. New Brunswick, NJ: Consortium for Research on Emotional Intelligence in Organizations, Rutgers University.

Cushner, K., \& Brislin, R. W. (1996). Intercultural Interactions: A Practical Guide. Thousand Oaks, CA: Sage.

Deardorff, D. K. (2006). Identification and assessment of intercultural competence as a student outcome of internationalization. Journal of studies in international education, 10(3), 241-266.

Engle, L., \& Engle, J. (2004). Assessing language acquisition and intercultural sensitivity development in relation to study abroad program design. Frontiers: The interdisciplinary journal of study abroad, 10, 219-236.

Gudykunst, W. B., \& Hammer, M. R. (1983). Basic training design: Approaches to intercultural training. Handbook of intercultural training: Issues in theory and design, 1, 118-154.

Hammer, M. R., Bennett, M. J., \& Wiseman, R. (2003). Measuring intercultural sensitivity: The intercultural development inventory. International journal of intercultural relations, 27(4), 421443.

Hart, R. P., Carlson, R. E., \& Eadie, W. F. (1980). Attitudes toward communication and the assessment of rhetorical sensitivity. Communications Monographs, 47(1), 1-22.

Jackson, J. (2011). Host language proficiency, intercultural sensitivity, and study abroad. Frontiers: The Interdisciplinary Journal of Study Abroad, 21, 167-188.

Kural, F., \& Bayyurt, Y. (2016). The implementation of an intercultural competence syllabus to prepare study-abroad students for global communication. Educational Studies, 42(4), 378-393.

Lo Bianco, J., Liddicoat, A. J., \& Crozet, C. (1999). Striving for the Third Place: Intercultural Competence through Language Education. Melbourne: Language Australia.

MacIntyre, P. D., Dörnyei, Z., Clément, R., \& Noels, K. A. (1998). Conceptualizing willingness to communicate in a L2: A situational model of L2 confidence and affiliation. The Modern Language Journal, 82(4), 545-562.

Patterson, S. C., \& Mughan, A. (1999). Senates: bicameralism in the contemporary world. Ohio State Univ Pr.

Penbek, Ş., Yurdakul Şahin, D., \& Cerit, A. G. (2012). Intercultural communication competence: A study about the intercultural sensitivity of university students based on their education and international experiences. International Journal of Logistics Systems and Management, 11(2), 232252.

Pfeffermann, D. \& Rao, C.R. (2009).Handbook of Statistics, Vol. 29B. The Netherlands: Elsevier.

Saricoban, A., \& Oz, H. (2014). Research into pre-service English teachers' intercultural communicative competence (ICC) in Turkish context. The Anthropologist, 18(2), 523-531.

Trochim, W. M., \& Donnelly, J. P. (2001). Research methods knowledge base (Vol. 2). Cincinnati, $\mathrm{OH}$ : Atomic Dog Publishing.

Vila Banos, R. (2006). The Affective Dimension of Intercultural Communication Competence in Compulsory Secondary Education: Intercultural Sensitivity Scale. Rie-Revista De Investigacion Educativa, 24(2), 353-372. 
Vygotsky, L. S. (1979). Consciousness as a problem in the psychology of behavior. Soviet psychology, 17(4), 3-35.

Wenger, E. (1999). Communities of practice: Learning, meaning, and identity. Cambridge: Cambridge university press.

Wertsch, J. V. (1994). The primacy of mediated action in sociocultural studies. Mind, culture, and activity, 1(4), 202-208.

Williams, T. R. (2005). Exploring the impact of study abroad on students' intercultural communication skills: Adaptability and sensitivity. Journal of studies in international education, 9(4), 356-371.

\section{Kültürlerarasi duyarlilik ile İngiliz dili kazanimi arasindaki ilişki}

\section{$\ddot{O} \mathbf{z}$}

Küreselleşen dünyada, farklı kültürel özelliklerle karşılaşmak ve farklı kültürel geçmişlerden gelen insanlarla etkileşim kurmak kaçınılmazdır. Günümüzde, kültürün dil öğrenimi ve dil öğretiminin temellerinden biri olduğuna inanılmaktadır. Avrupa Konseyi, kültür kavramını Avrupa bağlamında açıklamayı amaçlamakta ve farklı kültürel geçmişten gelen insanlar arasındaki kültürel farklılıkları ve kültürlerarası iletişimi teşvik etmeye çalışmaktadır. Kültürlerarası iletişimi teşvik etmeyi amaçlayan bu girişimler ışığında, bu çeşitliliğe uyum sağlamak ve faydalanmak mevcut eğitim sisteminin de iyileştirilmesi için yardımcı olacaktır.

$\mathrm{Bu}$ betimleyici çalışmanın amacı, Türkiye'de İngilizce'yi yabancı dil olarak öğrenenlerin kültürlerarası duyarlılıkları ve İngilizce dil kazanımları arasında bir ilişki olup olmadığını araştırmaktır. Çalışmanın amacı için nicel veri toplama metodolojisi kullanılmıştır. Kadın katılımcıların sayısı 120, erkek katılımcıların sayısı ise 205 'dir. Çalışmaya bir devlet üniversitesinde yabancı dil hazırlık okuyan rastgele küme örnekleme metoduyla seçilmiş toplam 325 öğrenciler katılmıştır. Niceliksel verileri elde etmek için Chen ve Starosta (2000) tarafindan geliştirilen "Kültürlerarası Duyarlılık Ölçeği” uygulanmıştır. Elde edilen veriler Sosyal Bilimler İçin İstatistik Programı (SPSS) ile analiz edilmiştir.

Araştırmanın bulguları, kültürlerarası duyarlılık ile İngilizceyi yabancı dil olarak öğrenenlerin İngilizce dil kazanımları arasında zayıf bir pozitif ilişki olduğunu göstermiştir. Bununla birlikte, katılımcıların kültürlerarası duyarlılık puanları ile İngilizce dil seviyeleri arasında anlamlı bir fark bulunmuştur. Sonuçlar, İngilizce dil seviyesi arttıkça, kültürlerarası duyarlılık puanlarının da yüksek olduğunu göstermiştir. Son olarak, kadın ve erkek katılımcıların kültürlerarası duyarlılık puanları arasında anlamlı bir fark bulunamamıştır. Elde edilen sonuçlara göre, kadın katılımcılar ve erkek katılımcılar birbirlerine yakın kültürlerarası duyarlılık puanına sahiptirler.

Anahtar sözcükler: kültürlerarası duyarlılık; İngilizce dil yeterliliği; kültürlerarası yeterlilik.

\section{AUTHOR BIODATA}

Fatma ÇILLĞLAN received her BA from English Language and Literature Department, Gaziantep University. She continued for further studies in the department of English Language Teaching at the same university. Currently, she is a Ph.D student in English Language Teaching Department at Çukurova University. She has been working as a Research Assistant in ELT department at Hasan Kalyoncu University. 